\title{
Study on Performance Evaluation Model and Index Systems of Administrative Service Centers
}

\author{
Shuo YANG ${ }^{\mathrm{a},{ }^{*}}$, Han LI ${ }^{\mathrm{b}}$, Li-Li CAO ${ }^{\mathrm{c}}$ \\ China National Institute of Standardization \\ No.4 Zhichun Road Haidian District, Beijing, China \\ ayangshuo@cnis.gov.cn, blihan@cnis.gov.cn, ${ }^{\mathrm{c}}$ caoll@cnis.gov.cn
}

Keywords: Administrative service, Performance evaluation, Key Performance Indicator (KPI).

\begin{abstract}
In this paper, we analyzed the status quo and existing problems of performance evaluation. Using KPI index design method, we constructed a performance evaluation model of administrative service according to the layers of administrative service activities. Such work has laid a foundation for putting theoretical research on performance evaluation of administrative service center into practical application, which can facilitate the quality promotion and development of administrative service centers.
\end{abstract}

\section{Introduction}

Since the late 1970s and early 1980s, the western developed countries have started to try novel government management modes, which promoted a wave of reforms on New Public Management Movement with the core of Government Reengineering. The governments then gradually shifted from control-type to service-oriented type. With the development and perfection of global economy, governments are urgent to explore more efficient, open, transparent, and responsible modes to meet the demand of reality. Administrative service center, however, represents an important window of government management in the information society. The performance level of administrative service center is directly related to working efficiency of government affairs, the process of democratic and information construction, the level of public services etc. Therefore, it is of great significance to explore the theories of performance evaluation of administrative service and its implementation in practice.

\section{Current Status and Revelation and Problems Analysis of Performance Evaluation of Administrative Service Centers}

The first administrative service center could date back to the British “one-stop” service. In the late 1970s and early 1980s, the British government tried its best to push administrative reforms after Margaret Thatcher came to office, in order to change the malpractice of expansion of service institutions, superfluous staff, low efficiency, severe inclination to departmental benefits etc. brought by traditional bureaucracy. One major action was to introduce the management mode of enterprises into government reform. Guided by such a reform thought, the "supermarket" management mode of enterprise was introduced into government administration. Thus, "one-stop” service center came into being in the UK. The UK was also among the earliest countries to implement government performance evaluation. In February 2009, seven organizations including the British National Audit Office, Office for Standards in Education etc. issued a comprehensive regional evaluation system based on the summary of previous performance evaluation forms, which was officially put into implementation in April 2009.

Australia's current APS and ROGS evaluation systems are comprehensive and standardized, the accumulated experience of which in practice has also been applied to the development of evaluation system of government service. The Australian government performance evaluation report has made a good progress, which can be attributed to the great influence of the steering committee, a supervision 
department, on the government sectors. The members of the steering committee come from core departments of central authorities and prefectural offices, such as State Prime Minister, finance minister etc. Such an institution has facilitated the promotion and development of government performance evaluation in Australia, and it also makes it possible to conduct cross-jurisdiction evaluation. At the same, Australian government gives full consideration to circumvention issues in the jurisdiction in the evaluation practice, claiming that each steering committee member not be able to participate in performance evaluation practice in their own jurisdiction. In the process of government performance evaluation, the Chinese government can set up the authority of the body of performance evaluation practice, so that the work can be recognized and understood by the government sectors and the public. In short, the revelation of the current work on performance evaluation of administrative service from developed countries is as follows:

a) The introduction of third party organization. In western countries, NGOs and the public are important players in the performance evaluation of local governments. With the development of performance evaluation practice, relevant professional organizations were established one after another, which brought in many practitioners (i.e., senators, civil autonomy committee members etc.) and theorists (scholars from institutions of higher learning or institutions for academic research) as consultants. The active participation of external agencies provides strong guarantee for the objectivity and impartiality of the evaluation, and media participation and public engagement also offers necessary provision for government performance evaluation. Such evaluation mode of multiparty participation is a typical characteristic of performance evaluation of local governments in the United States.

b) The purpose is to gain social public interests. From the perspective of international experiences, profit organizations and non-profit organizations should be strictly distinguished from each other when implementing performance evaluation, and evaluation index systems be determined based on the nature of the organization. As for administrative service center, the aim of its establishment is to focus on providing convenience service. Compared with social management function, the main task of administrative service center is to provide public services. Therefore, The core of performance evaluation of administrative service center should be based on indicators of social and public interests instead of economic indicators. For a long time, however, the development goal of the Chinese government has been guided by economic development, which can be reflected in the prevalent "worship of GDP" in government performance evaluation system. Entering the 21st century, such situation has been improved under the guidance of scientific outlook on development. GDP, however, still plays a dominant role in the performance evaluation of governments of all levels.

Since the middle and late 1990s, different forms of administrative service centers started to emerge across China. By the end of 2010, China had established 2842 comprehensive administrative service centers, including 10 of provincial level, 356 of municipal or prefectural level, 2476 of county or city level. Besides, 24849 villages and towns or sub-districts had established their own convenience service centers. With integrated functions of administrative examination and approval, administrative service centers have initially provided high quality and efficient service functions to citizens and enterprises in a centralized manner, by providing administrative information, administrative examination and approval, convenience service etc., which has been widely received and recognized by all sectors of society. In recent years in particular, such an organizational form has gradually spread to district or county-level cities, and played an increasingly important role in regular administrative work. Although China has experiences in the evaluation of civil servants at all levels, the founding of its evaluation system is still at the primary stage. Overall, China is at the exploring and pilot stage in the assessment of administrative service quality of governments. There are several deficiencies as follows:

First, the laws and regulations need urgent improvement and perfection. Currently, the administrative service quality evaluation systems have been developed by government at all levels in China in the absence of corresponding laws and regulations, making the evaluation work to be temporary and interim, which directly exerts negative impact on its validity and influence. 
Second, the imperfect index system determines the unstable evaluation performance. An effective government appraisal method is the key to successful government performance evaluation. Without a reliable evaluation system, it will be difficult to implement the government performance evaluation effectively. Currently, local governments put economic indicators at the core of their evaluation systems, many of which are established to their own convenience, leading to severe problems in obtaining objective and impartial evaluation results.

Third, evaluation results have not been applied in real work. The performance evaluation of the Chinese government is still at the primary stage. Since there is no effective institutional guarantee, the results of examination and evaluation stop there, without being intermingled with real work. So it does not promote the actual work, which causes the loss of original motivation of the evaluation. Only by applying the evaluation results into actual work can the authority and credibility of the government be consolidated.

\section{Selection of Performance Evaluation Index Models of Administrative Service Center}

Administrative service center is a non-profit governmental organization. Based on the analysis of the above-mentioned theoretical models, the commonly used performance evaluation models for government organizations include Delphi method, public opinion test, KPI method and 360-degree feedback method. Delphi method and public opinion test, however, have obvious limitations due to their instability and strong dependence. To sum up, the theoretical model for constructing the performance evaluation system of the administrative service center was mainly based on KPI performance evaluation model, which was added with certain comprehensive subjective evaluation indicators such as public satisfaction etc.

KPI indicators are usually selected from three types: uphill-type post, flat road-type post, and downhill-type post. In this paper, we employed downhill-type post. Downhill-type post indicators usually include big indicators and small indicators, and each big indicator further includes several small indicators. Detailed information and model is presented as in Figure 1.

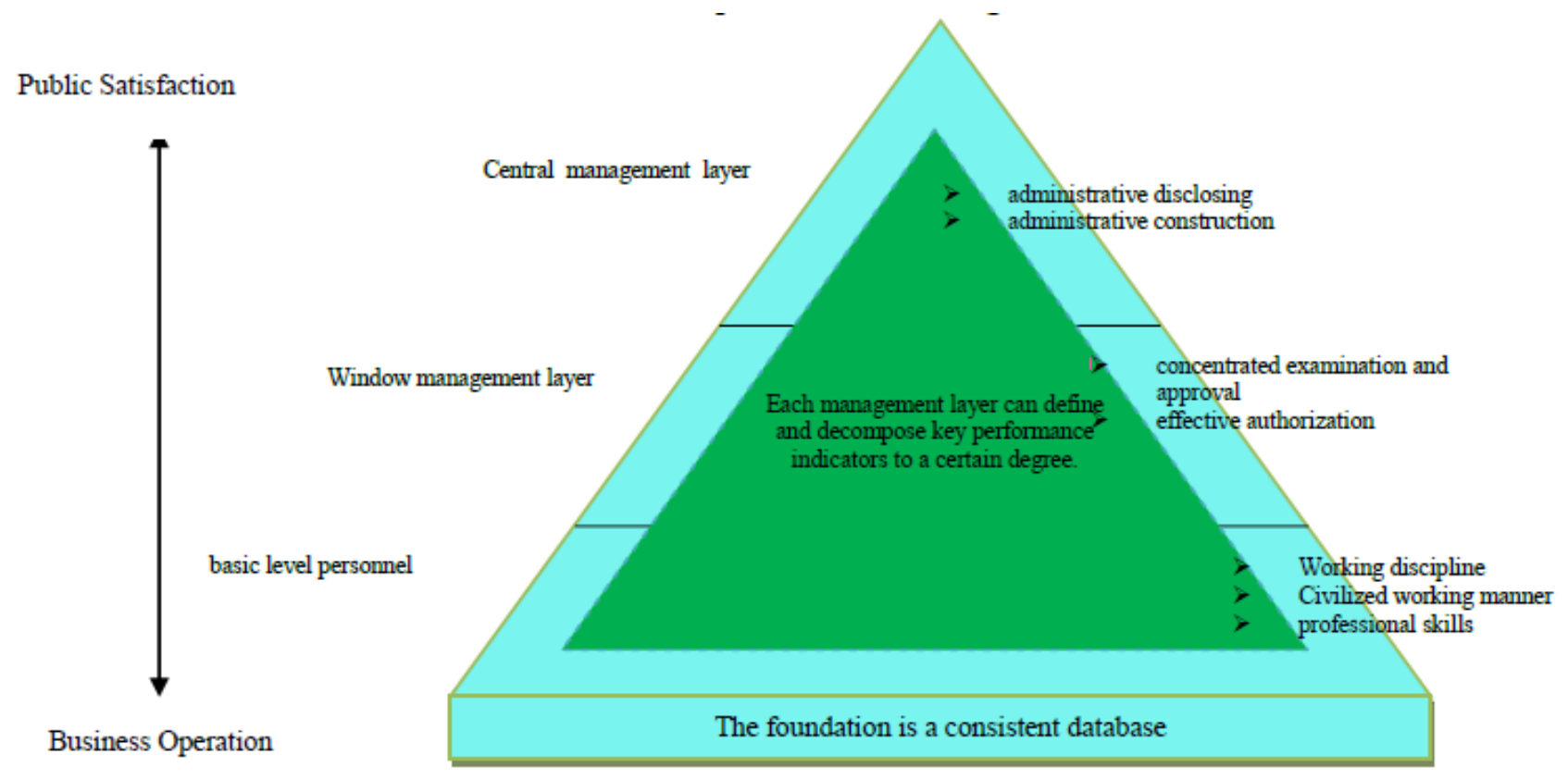

Figure 1 Diagram of KPI model of performance evaluation of administrative service center

\section{Design of Performance Evaluation Indicator System of Administrative Service Center}

According to the theoretical study of various performance evaluation indicators and the survey analysis of current administrative service centers, it's known that the evaluation of administrative 
service center is influenced by a number of factors with a complicated structure. Based on KPI performance evaluation model and characteristics of administrative service, three evaluation indicator systems are designed in terms of service center, service window and window staff, three levels having major influence over administrative service quality. Details are as follows:

a) Design of evaluation model of center, Table 1 shows the model of evaluation factor system of administrative service center:

Table 1: Performance evaluation model of center

\begin{tabular}{|c|c|c|c|}
\hline NO. & $\begin{array}{r}\text { Primary } \\
\text { indicator }\end{array}$ & Secondary indicator & $\begin{array}{l}\text { Nature of } \\
\text { indicator }\end{array}$ \\
\hline \multirow{4}{*}{1.} & \multirow{4}{*}{$\begin{array}{l}\text { Infrastructure } \\
\text { (A11) }\end{array}$} & Per capital service area of service user (B11) & Quantitative \\
\hline & & Parameter of overall quality of service staff (B12) & Quantitative \\
\hline & & Parameter of information infrastructure (B13) & Quantitative \\
\hline & & Overall service environment (B14) & Qualitative \\
\hline \multirow{3}{*}{2.} & \multirow{3}{*}{$\begin{array}{l}\text { E-government } \\
\text { construction } \\
\text { (A12) }\end{array}$} & Construction of e-government platform (B15) & Qualitative \\
\hline & & E-government operation (B16) & Qualitative \\
\hline & & E-supervision system (B17) & Qualitative \\
\hline \multirow[b]{2}{*}{3.} & \multirow{2}{*}{$\begin{array}{l}\text { Institutional } \\
\text { construction } \\
\text { (A13) }\end{array}$} & Construction of management system (B18) & Qualitative \\
\hline & & Construction of business system (B19) & Qualitative \\
\hline \multirow{2}{*}{4.} & \multirow{2}{*}{$\begin{array}{c}\text { Public image } \\
\text { building (A14) }\end{array}$} & Superior's comments (B110) & Quantitative \\
\hline & & Media report (B111) & Quantitative \\
\hline \multirow{3}{*}{5.} & \multirow{3}{*}{$\begin{array}{l}\text { Disclosure of } \\
\text { administration } \\
\text { (A15) }\end{array}$} & Disclosure of basic information (B112) & Qualitative \\
\hline & & Disclosure of handling instruction (B113) & Qualitative \\
\hline & & Disclosure of handling progress (B114) & Qualitative \\
\hline \multirow{3}{*}{6.} & \multirow{3}{*}{$\begin{array}{c}\text { Centralized } \\
\text { administration } \\
\text { and proper } \\
\text { authorization } \\
\text { (A16) }\end{array}$} & $\begin{array}{l}\text { Rate of administrative approval departments moving } \\
\text { in to the center (B115) }\end{array}$ & Quantitative \\
\hline & & $\begin{array}{l}\text { Rate of public service cases transferred to the center } \\
\text { (B116) }\end{array}$ & Quantitative \\
\hline & & Rate of windows with full authorization (B117) & Quantitative \\
\hline \multirow{3}{*}{7.} & \multirow{3}{*}{$\begin{array}{c}\text { Parallel } \\
\text { approval (A17) }\end{array}$} & Parallel approval rate of joint handling cases (B118) & Quantitative \\
\hline & & Construction of parallel approval system (B119) & Qualitative \\
\hline & & Rate of parallel approval cases fulfilled in time (B120) & Quantitative \\
\hline \multirow{3}{*}{8.} & \multirow{3}{*}{$\begin{array}{l}\text { People-oriented } \\
\text { service (A18) }\end{array}$} & Reservation service (B121) & Qualitative \\
\hline & & Interactive service (B122) & Qualitative \\
\hline & & Satisfaction rate of the public (B123) & Quantitative \\
\hline
\end{tabular}

$(B 11)=$ total area of administrative service center/total number of service users

$(B 12)=$ total score of certificate/total number of staff

(Scoring: junior college diploma $=2$ points, undergraduate diploma $=4$ points, diploma of postgraduate or above $=8$ points, NCRE certificate level 2 or above $=1$ point)

$(\mathrm{B} 13)=$ number of computers + network communication + servers

$(\mathrm{B} 110)=($ number of praise - number of criticism $) /$ total number of comments

$(B 111)=($ number of positive reports - number of negative reports)/total number of media reports

$(B 115)=$ departments moving in to the center/total number of administrative approval departments

$(B 116)=$ number of public service cases transferred to the center/total number of public service cases

$(\mathrm{B} 117)=$ number of windows with full authorization/total number of windows moving in

$(B 118)=$ number of parallel approval cases/total number of joint handling cases

(B119) = number of parallel approval cases fulfilled in time/total number of parallel approval cases

For other subjective evaluation indicators, it is expected to provide subjective evaluation according to comprehensive requirements of corresponding standard, and a 10-point system will apply.

b) Design of evaluation model of window, Table 2 shows the model of evaluation factor system of administrative service window: 
Table 2: Performance evaluation model of service window

\begin{tabular}{|c|c|c|c|}
\hline No. & $\begin{array}{l}\text { Primary } \\
\text { indicator }\end{array}$ & Secondary indicator & $\begin{array}{l}\text { Nature of } \\
\text { indicator }\end{array}$ \\
\hline \multirow[b]{2}{*}{1.} & \multirow{2}{*}{$\begin{array}{c}\text { Centralized } \\
\text { administrative } \\
\text { approval (A21) }\end{array}$} & Rate of cases centralized for administrative approval (B21) & Quantitative \\
\hline & & $\begin{array}{l}\text { Concentration of administrative approval departments and staff } \\
\text { (B22) }\end{array}$ & Quantitative \\
\hline \multirow{5}{*}{2.} & \multirow{5}{*}{$\begin{array}{c}\text { Proper } \\
\text { authorization of } \\
\text { administrative } \\
\text { approval (A22) }\end{array}$} & Decision-making power of chief representative (B23) & Qualitative \\
\hline & & Approval escalating authority & Qualitative \\
\hline & & Organization and coordination authority (B25) & Qualitative \\
\hline & & Window administration authority (B26) & Qualitative \\
\hline & & Access to seal (B27) & Qualitative \\
\hline \multirow{5}{*}{3.} & \multirow{5}{*}{$\begin{array}{l}\text { Parallel approval } \\
\quad \text { (A23) }\end{array}$} & Construction of parallel approval system (B28) & Qualitative \\
\hline & & Proper responsibility of parallel approval (B29) & Qualitative \\
\hline & & Operation of parallel approval (B210) & Qualitative \\
\hline & & Rate of being a leader in parallel approval (B211) & Quantitative \\
\hline & & Rate of participation in cases fulfilled in time (B212) & Quantitative \\
\hline \multirow{4}{*}{4.} & \multirow{4}{*}{$\begin{array}{l}\text { E-administration } \\
\quad \text { (A24) }\end{array}$} & Rate of timely reply to online inquiry (B213) & Quantitative \\
\hline & & Rate of successful online reservation (B214) & Quantitative \\
\hline & & Rate of online pre-approval fulfilled in time (B215) & Quantitative \\
\hline & & Rate of online approval fulfilled in time (B216) & Quantitative \\
\hline \multirow{5}{*}{5.} & \multirow{5}{*}{$\begin{array}{l}\text { Professional skill } \\
\quad \text { (A25) }\end{array}$} & On-site fulfillment rate (B217) & Quantitative \\
\hline & & Timely fulfillment rate (B218) & Quantitative \\
\hline & & Satisfaction rate of the public (B219) & Quantitative \\
\hline & & Quantity relative ratio of fulfillment (B220) & Quantitative \\
\hline & & Rate of fulfillment ahead of time (B221) & Quantitative \\
\hline \multirow{3}{*}{6.} & \multirow{3}{*}{$\begin{array}{c}\text { System } \\
\text { implementation } \\
\text { (A26) }\end{array}$} & Asking system of job responsibility (B222) & Qualitative \\
\hline & & System of fulfillment within limited time (B223) & Qualitative \\
\hline & & System of accountability (B224) & Qualitative \\
\hline \multirow[b]{2}{*}{7.} & \multirow{2}{*}{$\begin{array}{c}\text { Development of } \\
\text { window service } \\
\text { (A27) }\end{array}$} & System of selection and rotation of window staff (B225) & Qualitative \\
\hline & & Standardized management of window staff (B226) & Qualitative \\
\hline \multirow{2}{*}{8.} & \multirow{2}{*}{ Plus item (A28) } & Praise by relevant media (B227) & Quantitative \\
\hline & & Outstanding innovation (B228) & Quantitative \\
\hline \multirow{2}{*}{9.} & \multirow{2}{*}{ Minus item (A29) } & Violation of relevant national regulations (B229) & Quantitative \\
\hline & & Criticism by news media (B230) & Quantitative \\
\hline
\end{tabular}

$(B 21)=$ number of cases for administrative approval in the center/total number of cases handled by relevant departments

$(B 22)=$ number of staff working at the center/total number of department staff involved in handling

The premise is that the responsible person has to move to the center, otherwise no point will be gained.

$(B 211)=$ number of being a leader in parallel approval/total number of parallel approval involving window

$(B 212)=$ number of parallel approval participated and fulfilled in time/total number of parallel approval involving window

$(B 213)=$ number of online inquiries relied in time/total number of online inquiries

$(B 214)=$ number of successful online reservation/total number of online reservation

$(B 215)=$ number of online pre-approval cases fulfilled in time/total number of online pre-approval cases

$(B 216)=$ number of online approval cases fulfilled in time/total number of online approval cases

$(\mathrm{B} 217)=$ number of cases fulfilled in time on site/total number of cases approved at the window

$(B 218)=$ number of approval cases fulfilled within agreed time limit/total number of cases approved at the window 
$(B 219)=$ number of cases with comment of satisfaction or above/total number of cases handled at the window

$(B 220)=$ total number of cases handled at the window/total number of cases handled at the center

$(B 221)=$ number of cased fulfilled ahead of time/total number of cases handled at the window

For other subjective evaluation indicators, it is expected to provide subjective evaluation according to comprehensive requirements of corresponding standard, and a 10-point system will apply.For (B227) to (B230), 1 point per item will be added to or deducted from the total score.

C) Design of evaluation model of window staff, Table 3 shows the model of evaluation factor system of administrative service window staff:

Table 3: Performance evaluation model of window staff

\begin{tabular}{|c|c|c|c|}
\hline NO. & $\begin{array}{l}\text { Primary } \\
\text { indicator }\end{array}$ & Secondary indicator & $\begin{array}{l}\text { Nature of } \\
\text { indicator }\end{array}$ \\
\hline \multirow{3}{*}{1.} & \multirow{3}{*}{$\begin{array}{c}\text { Working } \\
\text { discipline (A31) }\end{array}$} & Attendance rate (B31) & Quantitative \\
\hline & & Rate of participation in activities organized by the center (B32) & Quantitative \\
\hline & & Compliance rate of operation (B33) & Quantitative \\
\hline \multirow{3}{*}{2.} & \multirow{3}{*}{$\begin{array}{c}\text { Manners and } \\
\text { compliance (A32) }\end{array}$} & Satisfaction rate of service (B34) & Quantitative \\
\hline & & Compliance with the center's working rules (B35) & Qualitative \\
\hline & & Compliance with the center's management (B36) & Qualitative \\
\hline \multirow{4}{*}{3.} & \multirow{4}{*}{$\begin{array}{l}\text { Professional skill } \\
\text { (A33) }\end{array}$} & Professional ability (B37) & Qualitative \\
\hline & & Spot check pass rate of reply to inquiry (B38) & Quantitative \\
\hline & & Number of cases fulfilled in time (B39) & Quantitative \\
\hline & & Rate of fulfillment ahead of time (B310) & Quantitative \\
\hline & \multirow{3}{*}{$\begin{array}{l}\text { Honesty and } \\
\text { self-discipline } \\
\text { (A34) }\end{array}$} & Honest work (B311) & Qualitative \\
\hline & & Fulfillment of duties (B312) & Qualitative \\
\hline & & Rate of effective complaints (B313) & Quantitative \\
\hline & \multirow{2}{*}{ Plus item (A35) } & Number of praise by media (B314) & Quantitative \\
\hline & & Number of adopted advice and suggestion (B315) & Quantitative \\
\hline
\end{tabular}

$(B 31)=$ days of regular attendance/total working days

$(B 32)=$ number of participation in activities organized by the center/total number of activities organized by the center

$(B 33)=$ number of cases fulfilled in compliance with rules/total number of cases participated

$(B 34)=$ number of cases with comment of satisfaction or above/total number of cases participated

$(\mathrm{B} 38)=$ number of passed spot checks of reply to inquiry/total number of replies to inquiry

$(B 39)=$ number of cases fulfilled in time/total number of cases participated

$(B 310)=$ number of cases fulfilled ahead of time/total number of cases participated

$(B 311)=$ number of effective complaints/total number of cases participated

For (B314) and (B315), 1 point per item will be added to or deducted from the total score.

For other subjective evaluation indicators, it is expected to provide subjective evaluation according to comprehensive requirements of corresponding standard, and a 10-point system will apply.

The followings are scoring rules of qualitative indicators in evaluating the performance of administrative service center. Due to the complexity of administrative service, it is infeasible to evaluate all of its performance by directly using objective indicators. In order to complement the KPI evaluation model, this study introduces many subjective evaluation indicators underpinned by the KPI-based evaluation model. Subjective evaluation should also refer to certain standards instead of arbitrary evaluation. Therefore, this study suggests that a scoring table should be designed for each subjective indicator to make clear the main factor to be considered and comprehensive scoring method, etc. On one hand, such design can ensure the consistency of the person in evaluating and scoring; on the other hand, separate standard documents and the documents corresponding to respective subjective indicators can be embedded into the application system of performance evaluation, which can improve the operability of the system. Table 4 shows the frame diagram of performance evaluation standard system of subjective indicators of administrative service center 
Table 4: Frame diagram of performance evaluation standard system of subjective indicators of administrative service center

\begin{tabular}{|l|l|}
\hline Performance evaluation standard system of subjective indicators of administrative service center \\
\hline \multirow{4}{*}{ Infrastructure } & Evaluation standard of overall service environment of administrative service center \\
\cline { 2 - 2 } & E-government construction \\
\cline { 2 - 2 } & Evaluation standard of e-government platform of administrative service center \\
\cline { 2 - 2 } Institutional & Evaluation standard of e-government operation of administrative service center \\
\cline { 2 - 2 } & Evaluation standard of e-supervision system of administrative service center \\
\cline { 2 - 2 } & Evaluation standard of management system of administrative service center \\
\cline { 2 - 2 } & Evaluation standard of business system of administrative service center \\
\hline \multirow{2}{*}{$\begin{array}{l}\text { disformation } \\
\text { disclosure }\end{array}$} & Evaluation standard of basic information disclosure of administrative service center \\
\cline { 2 - 2 } & Evaluation standard of handling instruction disclosure of administrative service center \\
\cline { 2 - 2 } & Evaluation standard of handling progress of administrative service center \\
\hline Parallel approval & Evaluation standard of handling progress of administrative service center \\
\hline \multirow{2}{*}{$\begin{array}{l}\text { People-oriented } \\
\text { service }\end{array}$} & Evaluation standard of reservation service of administrative service center \\
\cline { 2 - 2 } & Evaluation standard of interactive service of administrative service center \\
\hline
\end{tabular}

Details on the rating of qualitative evaluation of administrative service center are presented as follows:

Table 5 Performance Rating Reference for Administrative Services Centers

\begin{tabular}{|c|c|c|c|}
\hline Indicators & 0-3 pts & 4-7 pts & 8-10 pts \\
\hline $\mathrm{B}_{1} 4$ & $\begin{array}{l}\text { The facility is inadequate, } \\
\text { with messy environment; } \\
\text { Software facilities are not } \\
\text { available or broken. }\end{array}$ & $\begin{array}{l}\text { The facility is worn out in } \\
\text { part, but is clean and tidy, } \\
\text { covering a size less than } \\
1,000 \mathrm{~m}^{2} \text {; } \\
\text { Software facilities are } \\
\text { available but inadequate. }\end{array}$ & $\begin{array}{l}\text { The facility is complete, clean and } \\
\text { tidy, covering a minimum size of } \\
1,000 \mathrm{~m}^{2} \text {; } \\
\text { Software facilities are adequate; } \\
\text { Rating monitoring system, screen } \\
\text { display and inquiry system are } \\
\text { available. }\end{array}$ \\
\hline $\mathrm{B}_{1} 5$ & $\begin{array}{l}\text { Unscientific and } \\
\text { undemocratic information } \\
\text { service; } \\
\text { Inefficient service to } \\
\text { people; } \\
\text { Lack of rigorous } \\
\text { accountability mechanism }\end{array}$ & $\begin{array}{l}\text { Information service open to } \\
\text { the public, but not in } \\
\text { scientific and democratic } \\
\text { manner; } \\
\text { Not proactive in serving } \\
\text { people; } \\
\text { Rigid management and lack } \\
\text { of responsibility }\end{array}$ & $\begin{array}{l}\text { Information service provided in } \\
\text { scientific and democratic manner; } \\
\text { Efficient service to people; } \\
\text { Having rigorous accountability } \\
\text { mechanism. }\end{array}$ \\
\hline $\mathrm{B}_{1} 6$ & $\begin{array}{l}\text { Cases for online } \\
\text { pre-examination account } \\
\text { for less than } 50 \% \text {; cases for } \\
\text { online process account for } \\
\text { less than } 50 \% \text {; cases for } \\
\text { online conclusion account } \\
\text { for less than } 50 \% \text {. }\end{array}$ & $\begin{array}{l}\text { Cases for online } \\
\text { pre-examination account for } \\
50 \% \text {; cases for online process } \\
\text { account for } 50 \% \text {; cases for } \\
\text { online conclusion account for } \\
50 \% \text {. }\end{array}$ & $\begin{array}{l}\text { Cases for online pre-examination } \\
\text { account for } 70 \% \text {; cases for online } \\
\text { process account for70\%; cases for } \\
\text { online conclusion account for } 70 \% \text {. }\end{array}$ \\
\hline $\mathrm{B}_{1} 7$ & $\begin{array}{l}\text { No electric surveillance } \\
\text { system }\end{array}$ & $\begin{array}{l}\text { Electric surveillance system } \\
\text { is installed but unmonitored; } \\
\text { The center is not able to } \\
\text { handle emergencies timely. }\end{array}$ & $\begin{array}{l}\text { Electric surveillance system is well } \\
\text { equipped; } \\
\text { The center is able to detect and } \\
\text { capture offenders in case of special } \\
\text { circumstances and handle } \\
\text { emergencies timely. }\end{array}$ \\
\hline $\mathrm{B}_{1} 8$ & $\begin{array}{l}\text { No relevant management } \\
\text { system; } \\
\text { Personnel shift scheduling } \\
\text { is inadequate. }\end{array}$ & $\begin{array}{l}\text { Relevant management } \\
\text { system is available, but the } \\
\text { coordination among } \\
\text { departments is inadequate; } \\
\text { when person on duty leaves } \\
\text { the counter, business } \\
\text { handling is suspended. }\end{array}$ & $\begin{array}{l}\text { Organize, coordinate, supervise and } \\
\text { service well; } \\
\text { Understand all kinds of performance } \\
\text { indicators precisely; } \\
\text { When person on duty leaves the } \\
\text { counter, he or she is reachable for }\end{array}$ \\
\hline
\end{tabular}




\begin{tabular}{|c|c|c|c|}
\hline & & & $\begin{array}{l}\text { confirmation of handling time, } \\
\text { requirements, etc. }\end{array}$ \\
\hline Indicators & $0-3$ pts & 4-7 pts & 8-10 pts \\
\hline $\mathrm{B}_{1} 9$ & $\begin{array}{l}\text { Inefficient business } \\
\text { handling; } \\
\text { Low customer satisfaction } \\
\text { rate }\end{array}$ & $\begin{array}{l}\text { Showing rigid adherence to } \\
\text { rules and lacking flexibility. }\end{array}$ & $\begin{array}{l}\text { Showing hospitality to customers, } \\
\text { proactive in customers' concerns } \\
\text { and delivering satisfactory reply. }\end{array}$ \\
\hline $\mathrm{B}_{1} 12$ & $\begin{array}{l}\text { Basic information is not } \\
\text { made public and promoted; } \\
\text { service channel and } \\
\text { information are blocked. }\end{array}$ & $\begin{array}{l}\text { Publicity and expansion } \\
\text { channels are limited, but } \\
\text { certain information are made } \\
\text { public; } \\
\text { Expanded services and } \\
\text { contents are not } \\
\text { communicated timely. }\end{array}$ & $\begin{array}{l}\text { E-government platform is promoted } \\
\text { via various channels; } \\
\text { Expanded services, contents and } \\
\text { features based on the platform are } \\
\text { adequate; } \\
\text { Promotional materials and } \\
\text { expanded contents are timely } \\
\text { delivered to the network service } \\
\text { center in forms of message, } \\
\text { newsletter, etc. }\end{array}$ \\
\hline $\mathrm{B}_{1} 13$ & $\begin{array}{l}\text { The number of outlets is not } \\
\text { published online; } \\
\text { Business handling guides } \\
\text { are not updated timely; } \\
\text { Instructions on business } \\
\text { handling are not available } \\
\text { in the hall of the center. }\end{array}$ & $\begin{array}{l}\text { Information on outlets and } \\
\text { handling guides are available } \\
\text { online, but are not the most } \\
\text { updated. } \\
\text { The hall of the center is } \\
\text { understaffed and thus cannot } \\
\text { deliver timely service; } \\
\text { Posters and flyers are not } \\
\text { evidently placed in the hall. }\end{array}$ & $\begin{array}{l}\text { There are convenience outlets and } \\
\text { the number of the outlets is } \\
\text { published online; } \\
\text { Regulations on business handling } \\
\text { are timely updated online; } \\
\text { Posters and detailed instructions on } \\
\text { business handling are available in } \\
\text { the hall and there is staff on site to } \\
\text { provide further explanation. }\end{array}$ \\
\hline $\mathrm{B}_{1} 14$ & $\begin{array}{l}\text { The number and progress of } \\
\text { cases handled are not } \\
\text { updated timely and there is } \\
\text { false conduct. }\end{array}$ & $\begin{array}{l}\text { The number and progress of } \\
\text { case handled are only given } \\
\text { upon requested. }\end{array}$ & $\begin{array}{l}\text { Cases are handled within set period } \\
\text { of time. }\end{array}$ \\
\hline $\mathrm{B}_{1} 19$ & $\begin{array}{l}\text { Handling overdue, low } \\
\text { evaluation rate, no } \\
\text { exclusive venue for } \\
\text { examination and approval; } \\
\text { No counter and personnel } \\
\text { for general business; } \\
\text { Unable to make timely } \\
\text { adjustments in change of } \\
\text { circumstances. }\end{array}$ & $\begin{array}{l}\text { There is exclusive venue for } \\
\text { examination and approval, as } \\
\text { well as counters and } \\
\text { personnel for general } \\
\text { business, but they do not } \\
\text { perform the functions } \\
\text { properly; } \\
\text { The center is able to make } \\
\text { adjustments according to the } \\
\text { actual circumstances, even } \\
\text { though not timely. }\end{array}$ & $\begin{array}{l}\text { There is exclusive venue for } \\
\text { examination and approval l, as well } \\
\text { as counters and personnel for } \\
\text { general business; } \\
\text { The center is able to make } \\
\text { adjustments to the actual } \\
\text { circumstances. }\end{array}$ \\
\hline $\mathrm{B}_{1} 21$ & $\begin{array}{l}\text { Appointments are not } \\
\text { handled timely and not } \\
\text { reach certain amount; } \\
\text { Customers who make } \\
\text { appointment are not } \\
\text { satisfied. }\end{array}$ & $\begin{array}{l}\text { Appointments are handled } \\
\text { within set period of time; } \\
\text { There is no convenience } \\
\text { service. }\end{array}$ & $\begin{array}{l}\text { Appointments are handled timely; } \\
\text { Convenience outlets provide } \\
\text { thoughtful services. }\end{array}$ \\
\hline $\mathrm{B}_{1} 22$ & $\begin{array}{l}\text { Customer satisfaction rate } \\
\text { is lower than } 60 \% \text {; cases } \\
\text { are handled in a delayed } \\
\text { manner, with the } \\
\text { conclusion rate is lower } \\
\text { than } 60 \% \text {. }\end{array}$ & $\begin{array}{l}\text { Cases are handled within set } \\
\text { period of time with the } \\
\text { conclusion rate between } 60 \% \\
\text { - } 80 \% \text {; } \\
\text { Customers' feedback do not } \\
\text { show dissatisfaction. }\end{array}$ & $\begin{array}{l}\text { Cases are handled in an efficient } \\
\text { manner with site conclusion rate } \\
\text { higher than } 95 \% \text {; } \\
\text { Customer satisfaction rate reaches } \\
90 \% \text {. }\end{array}$ \\
\hline
\end{tabular}

\section{Summary}

Based on the aforesaid, the combination of objective and subjective evaluation, specifically, the rating based on subjective and objective indicators, can prevent arbitrary and unfair nature of 
subjective evaluation on the one hand, and on the other hand counteract the rigidity in objective indicators that fail to take into account soft factors like attitudes, thus forming more scientific and better KPI system for administrative services organizations.

\section{Acknowledgement}

This research was financially supported by the China National Institute of Standardization.

\section{References}

[1] J. van der Geer, J.A.J. Hanraads, R.A. Lupton, The art of writing a scientific article, J. Sci. Commun. 163 (2000) 51-59.

Reference to a book:

[2] W. Strunk Jr., E.B. White, The Elements of Style, third ed., Macmillan, New York, 1979.

Reference to a chapter in an edited book: 